Innovation of Vocational Technology Education

Available online at http://ejournal.upi.edu/index.php/invotec

\title{
V
}

invotec

\section{Development of Competency Based Assessment Model on Job Performance in Family Welfare Education Apprenticeship}

\author{
Yoyoh Jubaedah, Neni Rohaeni \& Nenden Rani Rinekasari
}

Universitas Pendidikan Indonesia, Indonesia

ARTICLE INFO

Article history:

Received 28 December 2016

Received in revised form 12

January 2017

Accepted 1 February 2017

Available online 28 February 2017

Keywords:

Job performance

Family welfare

Competency based assessment

Corresponding author:

yoyohjubaedah@upi.edu
A B S TR A C T

The assessment tool to evaluate learner performance on the apprenticeship is variety. Therefore, we were need a standardized assessment tool. This study was attempt to develop a competency based assessment model on job performance in apprentice of the family welfare education. Problem solving was conducted using research and development approach, through stages of: (1) a study introduction, (2) a development model, and (3) a validation model. The research subjects are internal and external tutors, also a learner intern. Data collection was carried out by interviews, observation, survey and expert judgment. The results showed that the planning, the instrument and the implementation of the assessment was the development of competency based assessment model on job performance in family welfare education apprenticeship. Planning assessment was consisting of components of the purpose, job performance, and assessment methods. An instrument assessment was use a test of performance in the form of assessment rubrics. The implementation of the assessment was covering a preparation, collecting, judging, deciding, and moderation stage. From the validation model through the expert judgment, it turns out that assessment model was already developed feasible to implement on job performance assessment in family welfare education apprenticeship.

\section{Introduction}

The Family Welfare Education Study Program or PKK Study Program is one of course at the Home Economics Department at the Faculty of Technological and Vocational Education in Universitas Pendidikan Indonesia. It is attempted to produce a qualified graduates. They are the scholar with academically and professionally education can contribute to improve the quality of human resources. 
Hence, they should demonstrate their abilities as follows: (1) As educator at formal education such as teachers at High School with social work expertise; hospitality accommodation, the craftsmanship design and product. (2) As educator at nonformal education such as instructor at the babysitter, elderly services or caregiver, craftsmanship design and production training institutes. (3) Family consultants, PKK counselors, and social worker assistant counselors. (4) As entrepreneur at: design and production of educational toys, design and production craftsmanship, daycare and hospitality (Profile of Family Welfare Education Study Program, 2015).

This profile graduates can be achieved when they were supported by service academic. It was a learning experience in the form of lectures and judgment in accordance with an Indonesian Qualification Framework. They should be demonstrate the ability to work, so they would gained a recognition from the work field. This ability was assumed to equip the learner in implementing the tasks of teach and professional with all change and demand. This assumption based on the conclusion from study result, that teachers candidates need to reach a skill thought with a high degree necessary to increase the quality of the future of Indonesia human resources (Liliasari, 2003).

To anticipate it, the PKK study programs were load by the theory and practice lectures. Lecture of theory is provides an understanding of the fundamental concept and insight of the implemented scientific in the form of lecture and response in the class. Lecture practices consist of: (1) increase skill practices and industry insight carried out in industries according to fields of expertise through the apprenticeship; (2) increase in perspectives practices and expertise of the teaching profession carried out in vocational schools in accordance with the field of expertise through the teacher internship.

The implementation of the curriculum in PKK Study Program especially to apprenticeship, it was referring to lecture science and expertise course that formulated in the curriculum such as social services, craftsmanship, house management and family life education. At the present, PKK Study Program have not an assessment model that capable to measuring learners work competences in the apprenticeship program. This finding is the reason it should be designed a competency based assessment model on job performance in the apprenticeship program at industries such social service agency, creative industry and hotels. Competency based assessment is a form of evaluation which includes planning stages, data collection, judgment, and decision making for the achievement of competence to fit the standard (Worsnop) 1993.

Competency based assessment is directed for measuring and assessing learners performance in the ability cognitive, psychomotor and affective; either directly on activity learning, and indirectly through evidence of learning in accordance with performance criteria. Performance criteria has to be in accordance with the demands of the field of work, because this competence must be recognition by the users. The results of a study form Birk (2005) reveal that the grades are often constituted by the confuse criteria. Based on a survey by Blount at the Georgia University, $82 \%$ from the results showed that the value is an effort to increase the learner's motivation to work harder.

\section{Method}

Research and development was used as research approach. Research and development in this study includes three phases, namely: 1) the preliminary study, 2) the development model and 3) the validation model (Sukmadinata, 2005). The study was held at industry in Bandung. They are a partnership institutions of PKK Study Program for the apprenticeship program; the research subjects are learners, supervising lecturer (internal), and practitioners of industry (external tutors).

Data collection research was divided into three parts, namely:

\subsection{Preliminary Study}

Technique interview, observation, study of documentation supplied with literature studies were chosen to produce a design model competency based assessment on job performance in family welfare education apprenticeship.

\subsection{Development model}

On that stage of development model, competency based assessment model on job performance in the apprenticeship family welfare education was trial; covering the limited and broader test to produce the model for validation. 


\subsubsection{Validation Model}

On stage of validation, model was implemented to test the excellence of the model that developed by validation experts and empirical.

Analysis techniques data was done includes data analysis at the introduction study, development model and validation through expert judgment model. It was analyzed qualitatively with description in the narrative share.

Research procedures with the research and development approach described in Figure 1.

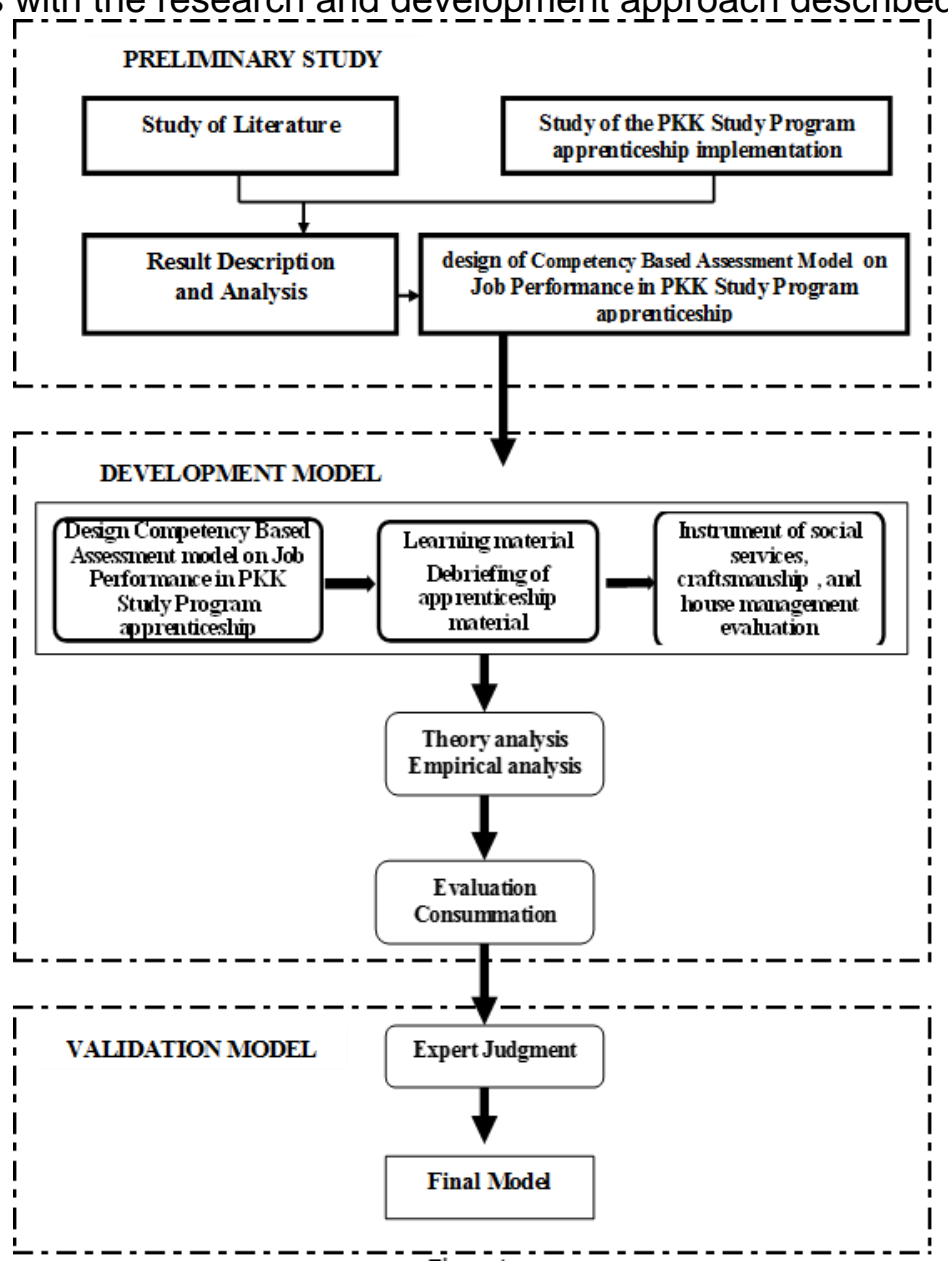

Figure 1. Research and development process the development of competency based assessment model on job performance in family welfare education apprenticeship

\section{Results and Discussion}

3.1 The condition of family welfare education study program apprenticeship

Family Welfare Education Study Program Apprenticeship was implemented in a block system in a semester. The partnership institutions chosen was institutions and industry that having a relevance characteristic with a competence that developed in a profile and an Indonesia Standard National Qualification of PKK study Program. It was social institutions (children and elderly social shelter), government agencies, creative industry and hotels Bandung. The learners job performance was evaluation by external parties, includes:

\subsubsection{Abilities to work, such as}

1) The application of knowledge in work is suitable with their scientific and expertise.

2) The skill work is suitable with their expertise.

3) The completion of a job is appropriate with the Standard Operational Procedure.

4) The completion of a job is suitable with the time allocation. 
3.1.2 Work conscientiousness, such as

1) Attention to the guidance of the institution leader

2) Thoroughness in the completion of a job

3) Neatness for work

4) Obedience to the rule

3.1.3 Work behavior, such as

1) Time management in work

2) Ability to cooperate

3) Participation in implementing the tasks

4) Concentrate on the job

3.2 Analysis of competency based assessment model on job performance in the implementation of family welfare education study program apprenticeship

Competency based assessment model on job performance in the implementation of Family Welfare Education Study Program Apprenticeship was adapting a procedures that includes: planning, instrument, and the implementation of the assessment.

\subsubsection{The planning assessment}

The development of competency based assessment model on job performance in the implementation of Family Welfare Education Study Program Apprenticeship pertaining to planning assessment components. It was covering the purpose, job performance, and a method of assessment and the duration of the period for implementation of assessment. The finding of all of the components were in line with the demands of the standard operating procedures, but it have to adaptation especially in the determination of the duration apprenticeship. This finding was analyzed from the results of verification of the industry by an external appraiser. They had an authorities to determine learner's achievement of work competence. Foyster stated that verification needs to be done in the planning judgment stages, because the substance of competence that must be controlled by a learners should be in accordance with the demands of the criteria. It have been used for performance as a standards of the world business and industry (Hall, 1995). It was a base for verification an external performed on the planning stages a judgment as procedure model judgment developed.

The measurement of competence for job performance was done through a method of assessment of performance test in the form of rubrics assessment in accordance with standards that has been agreed upon by an internal and external appraiser referring to Standard Operational Procedure of partnership industry.

\subsubsection{Instrument of assessment}

Instrument of assessment as the development of assessment model stage was done through the activities of: 1) Arranging of assessment clues, 2) Drafting of instrument assessment, 3) Developing a performance criteria and 4) testing the quality of an instrument see through expert judgment.

Arrangement of assessment clues ware referring to planning the evaluation that has been verified by the industry parties as assessors external. It was contain the job performance that must be controlled by the learner on the fields of social service, craftsmanship, and house management expertise.

Draft of instrument assessment in performance test was verified by industry as an external appraiser. An instrument of performance test was made in the form of performance that must be indicated by learners which includes the preparation of a workplace, the process of working, the attitude of work, and a product that produced by the use of the scale of an assessment. It was equipped with a performance criteria as assessment guidebook. Performance criteria was developed to give a reference for an appraiser in giving an assessment to the learner objectively, because an internal and external appraiser requires a deal at in evaluation. Cropley stated that an instrument assessment produced was tested by the quality of an instrument test through expert judgment. It was done in an effort to produce an instrument really judge that are assessed and yielding instrument capable of being dependable or trusted, and stable in evaluate a learner competence (Hall, 1955 ). 


\subsubsection{The evaluation implementation}

The evaluation was a planning and instrument implementation which has developed in the basic skills of social services, craftsmanship and house management. The model initially developed was consisting of four stages; in the preparation, collecting, judging and deciding stage that adapted from competency based assessment (Worsnop, 1993). This assessment model was evolved through the study theoretical and expert judgment; now, it is covering the: 1) preparation, 2) collecting, 3) judging, 4) deciding, and 5) moderation.

Stage preparation are the briefing of materials activities about job performance in related apprenticeship industries that must be controlled by learner in accordance to the SOP industry demands as a partnership institution. Collecting, judging, deciding and moderation stage were held by supervising lecturer as an internal assessors, and industry as an external assessors. It was an objective evidence through collection an adequate evidence to show that a person can carry out or attitude in accordance particular standard in a particular role (Fletcher, 2005).

3.3 The development of competency based assessment model on job performance in the implementation of family welfare education apprenticeship

Competency based assessment model on job performance in the implementation of family welfare education apprenticeship was produced through research and development, involving planning, instrument, and implementation assessment of the social services, craftsmanship, and house management expertise.

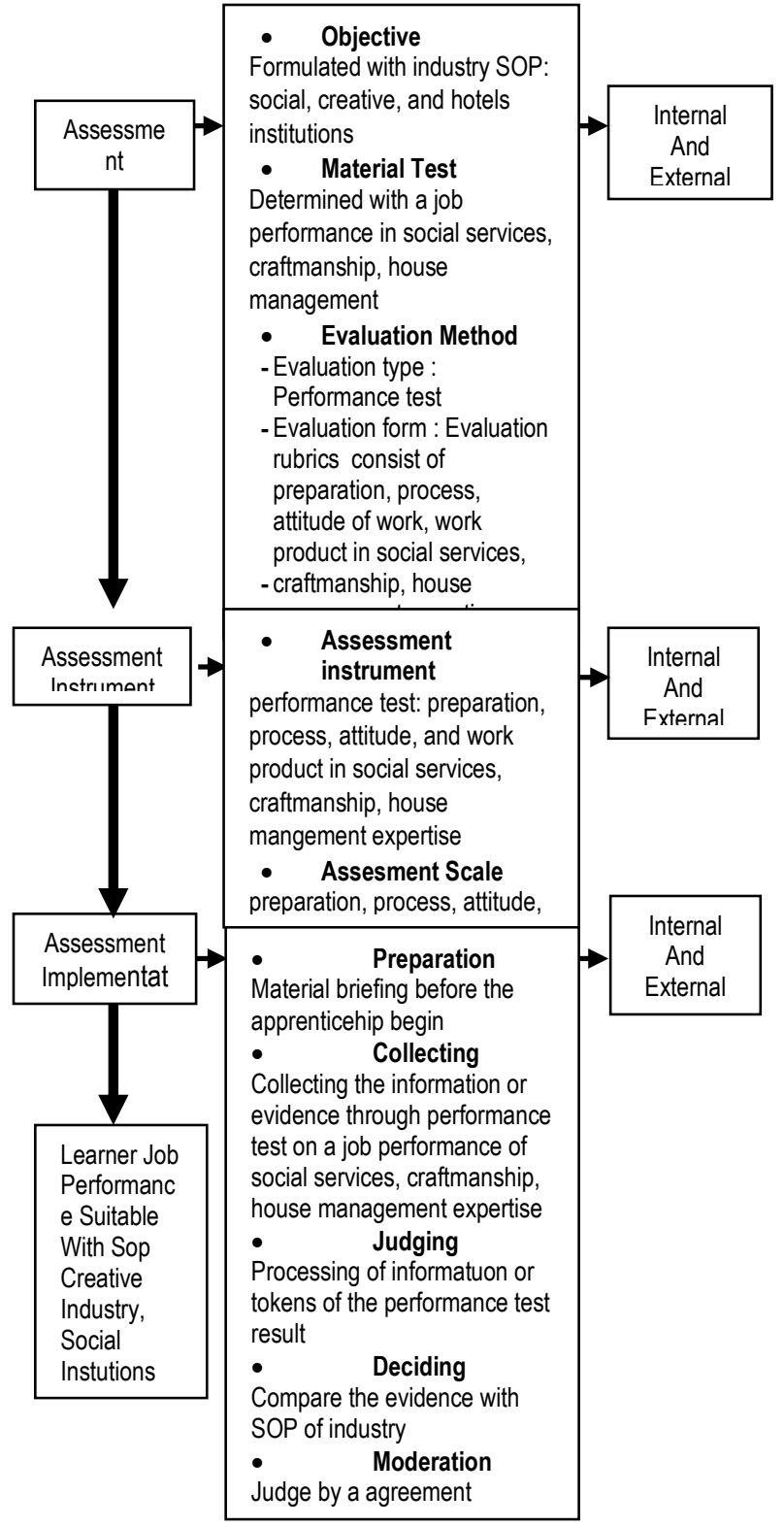

Figure 2. Competency based assessment model on job performance in the implementation of family welfare education apprenticeship 
Design model of competency based assessment on job perfomance in family welfare education apprenticeship focused on fields of social services, craftsmanship and house management expertises; includes:

\subsubsection{Planning assessment}

Evaluation planning was designed covering an aspects as follows:

1) Formulating the purpose of assessment was referring to industry standard operating procedures as partnership institution in the implementation apprenticeship, namely social institutions, creative industries and hotel.

2) Designing the matter for debriefing was referring to industry SOP. It was gathering an evidence of learner work competence in preparing a workplace, the process of working, attitude, and products work as a result of working in the field of social services, craftsmanship, and house management expertise.

3) Designing the assessment method was reference to the level of competence that must be assessed in job performance in family welfare education apprenticeship.

4) Determining the allocation of the implementation time practice industry was refers to the guidelines of the apprenticeship in Faculty of Technological and Vocational Education.

\subsubsection{Instrument of assessment}

The instrument assessment was done through the following activities:

1) Arranging of assessment instruments clues includes all components to be accommodated in the process that appropriate with a job performance of industry SOP.

2) Drafting assessment instrument that referring to the objectives and assessment instrument clues. Performance tests was arranged in the form of working that consisting of the preparation, attitudes and process of working. Also in making the product and quality assessments of the product as a result of working.

3) Drafting of performance criteria was referring to the aspects that measured in accordance with work procedures, thus produced a guidelines assessment performance test that appropriate with the industrial SOP.

4) Testing the quality of an instrument by the assessment in theoretical and expert judgment, thus produced an instrument are valid and reliable and worthy of to implement.

\subsubsection{The implementation of the assessment}

In the implementation of the assessment, learner competence performance was covering steps:

1) Preparation

The preparatory stage was done through the activities of an apprenticeship materials briefing that given by the PKK Study Program before they carried out the apprenticeship. Briefing of materials as learning experience is able to contribute to achievement of learner competence performance in accordance with job performance of industry SOP

2) Collecting stage

The collection of information or evidence was done through a performance test in accordance to job performance, involving lecturers as internal assessors and industry as external assessors.

Internal and external assessor was evaluate a readiness of learner in preparing materials and tools that appropriate to job performance, observations on the process of work, and work ethic, assessment of a product produced by the use of assessment scales that has been equipped with performance criteria. Granting score referring to assessment guidebook aspect in accordance with who is assessed and performance criteria.

3) Judging

Processing information stage was undertaken through the activities of the provision of the score in accordance with the directive assessment. Lecturers as an internal assessors was process evidence that mustered by the industry as assessors external.

4) Deciding

Consideration stage was done through the activities that involving assessors internal and external by means of compare the evidence by industry standards. Comparison evidence with a standard is a final value of these achievement learner competence as a result consideration assessors internal and external. 


\section{5) Moderation}

Decision-making stage was done through verification activity at the end or moderation after conducted testing to learner competence. An internal appraiser was cooperate with external assessors to clarification to find an agreement in judge to these achievement learner competence performance.

Competency based assessment model on job performance in the implementation of family welfare education apprenticeship was produced as the final model. It had eligibility for implemented in the implementation of the performance in family welfare education apprenticeship, in judging their achievement of performance competence on the fields of social services, craftsmanship, and house management expertise. Feasibility was obtained through expert judgment and practitioners, who provide recommendations that model the result of developing having eligibility for used in the implementation of family welfare education apprenticeship at related industries such as, institutions social, creative industry and hotels.

\section{Conclusions}

1) The family welfare education apprenticeship education was implemented in block system in a semester in the relevant to graduate profile and Indonesia Standard National Qualification at social institutions such as social children and elderly shelter, creative industry and hotels in Bandung.

2) The competency based assessment model on the job performance in of family welfare education apprenticeship produced was covering the planning, instrument, and the evaluation implementation on fields of social services, craftsmanship, and house management expertise's.

3) The evaluation was measured a job performance of the of family welfare education apprenticeship, includes preparation, collecting, judging, deciding , and moderation

4) Competency based assessment model are having an eligibility for implemented on evaluate a job performance of family welfare education apprenticeship in fields of social services, craftsmanship and house management expertise's.

\section{References}

Birk, L. 2005. Grade Inflation: What's Really Behind All Those A's?. [Online]. http://jalt.org/test/ cro_1.htm..html. (14 Oktober 2005).

Fletcher, S. 2005. The Art of Training and Development: Competence-Based Assessment Techniques. Translated by Ramelan. Teknik Penilaian Berbasis Kompetensi. Jakarta: PT Bhuana Ilmu Populer.

Hall, M.C. 1995. Key Aspects of Competency-based Assessment. South Australia: National Centre for Vocational Education Research Ltd.

Liliasari. 2003. Pengembangan Keterampilan Berpikir Tingkat Tinggi Mahasiswa Caon Guru melalui Model Pembelajaran Kimia. Bandung: Mimbar Pendidikan No. 2/XXII/2003.

Program Studi Pendidikan Kesejahteraan Keluarga. 2015. Profil Program Studi Pendidikan Kesejahteraan Keluarga. Bandung: Universitas Pendidikan Indonesia.

Sukmadinata, N.S. 2005. Metode Penelitian Pendidikan. Bandung: PT Remaja Rosdakarya.

Wosnop, P.J. 1993. Competency Based Training: How to Do it - For Trainers. VEETAC: Developing for the Competency Based Training Working party. 